\title{
Reversible Hepatotoxicity of Cassytha filiformis Extract: Experimental Study on Liver Function and Propofol-Induced Sleep in Mice
}

\author{
Yori Yuliandra, Armenia Armenia*, Rahmad Arief, Mifta Hul Jannah, Helmi Arifin
}

\section{Yori Yuliandra, Armenia Armenia*, Rahmad Arief, Mifta Hul Jannah, Helmi Arifin}

\section{Department of Pharmacology and Clinical Pharmacy, Faculty of Pharmacy, Andalas University, Padang, West Sumatra, INDONESIA. \\ Correspondence \\ Prof. Armenia Armenia \\ Faculty of Pharmacy, Andalas University, Campus Limau Manis, Pauh, Padang, West Sumatra, 25163, INDONESIA. \\ Phone no : +62751-71682 \\ E-mail: armenia@phar.unand.ac.id \\ History \\ - Submission Date: 19-04-2018. \\ - Review completed: 07-08-2018; \\ - Accepted Date: 15-11-2018}

DOI : 10.5530/pj.2019.1.13

Article Available online

http://www.phcogj.com/v11/i1

\section{Copyright}

(C) 2019 Phcog.Net. This is an openaccess article distributed under the terms of the Creative Commons Attribution 4.0 International license.

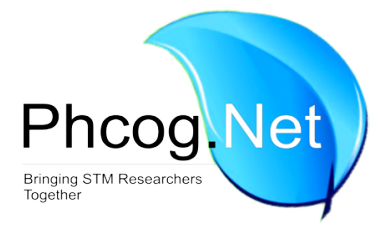

\begin{abstract}
Objective: To study the liver toxicity of Cassytha filiformis L. extract and its reversibility in mice. Methods: A total of 108 male mice were used to investigate the hepatotoxicity of Cassytha filiformis extract (CFE) and the reversibility of its toxicity to the liver. Seventy-two mice were treated with CFE orally for 7 consecutive days. A half of these animals were used to study the sleep time on propofol-induced sleep that comprised the sleep onset time (SOT) and duration of sleep (DOS), while another half was used for the quantitation of serum alanine transaminase (ALT) activity. To investigate the reversibility of the liver toxicity, thirty-six mice were treated with daily CFE for 7 days. Activities of ALT and alkaline phosphatase (ALP) were determined and the liver weight ratio was measured on day $0,1,3$ and 7 after the termination of the CFE treatment. Data of liver toxicity determination were analyzed by two-way ANOVA followed by Duncan's multiple range test, while data of the reversibility was analyzed by Pearson's correlation. The significance level was taken at 95\% of confidence interval. Results: CFE shortened the SOT and prolonged the DOS significantly compared with control $(p<0.05)$. The activity of ALT was increased due to the toxicity of CFE. However, the ALT/ALP activities decreased and liver weight ratio increased gradually after the extract treatment was discontinued. The trend of these data was correlated significantly $(p<0.05)$. Conclusion: Cassytha filiformis L. extract is toxic to the liver but the toxicity is reversible depending on doses. Key words: Cassytha filiformis, Reversible toxicity, Liver function, Propofol, Sleep time.
\end{abstract}

\section{INTRODUCTION}

A concept in traditional medicine called 'natural is safe' has been developing and led the massive use of herbal products for health benefits. This concept in some cases is not only far from the truth, but can also be dangerous. Some of the most toxic substances to human body come from nature. When a synthetic drug that contains a single active chemical substance can be toxic, more potential toxic effects are likely expected from a natural herb which may contain hundreds of chemical compounds. ${ }^{1}$ Many cases of serious adverse reactions from the consumption of herbal medicine have been reported across the globe. ${ }^{2-4}$ In addition, the adverse reactions of herbal medicine are also experienced by patients treated in hospital settings who receive conventional medications. ${ }^{5}$

Undesired effects of traditional medicine may include allergic reactions, toxic reactions and interactions. These effects can be due to several factors, such as inappropriate doses and length of use, bacterial or other chemical contaminations and mistaken plant identities. The safe use of traditional medicines has been a major concern since they have led to several adverse reactions that can be life-threatening. ${ }^{6-8}$ Therefore, it is necessary to conduct toxicological studies to better provide their feasibility and utilization. WHO has encouraged countries to promote the safe use of herbal products by stimulating strategic research on the safety of traditional medicine intended for health benefits. ${ }^{9}$

Following several reports on the traditional use of Cassytha filiformis as herbal medicine, the potential pharmacological activities of this plant have been extensively reported within the last decade. The plant effect comprises several activities in a wide range of physiological systems, mainly cardiovascular function. Many studies have proven that this herbaceous plant exhibits antiplatelet and vasorelaxing effect, ${ }^{10}$ antihypertensive, ${ }^{11-12}$ diuretic effect ${ }^{13}$ and blood glucose lowering effect. ${ }^{14}$ Other studies have also confirmed different effects of the plant, including uterotonic, ${ }^{15}$ anticancer, ${ }^{16-17}$ immunosuppressive $^{18}$ and anti-infectious. ${ }^{17,19-20}$ These properties make this plant a very promising herbal medicine for the development of pharmaceuticals. However, toxicological studies on this potential medicinal plant are still limited. 
The toxicity studies on various extracts and fractions of $C$. filiformis have shown varying results in experimental animals. Most of them suggest that the plant is generally non-toxic for most organ systems, such as for the haematologic functions, plasma biochemical parameters, ${ }^{21}$ and kidney functions.22 Our previous study has also highlighted that the acute administration of ethanolic extract of this plant does not affect the organ weight ratio of some major organs, but may cause delayed toxicity, including to the liver. ${ }^{23}$

Liver cells are well known to have a remarkable ability to regenerate compared to other organs. ${ }^{24}$ The damaged cells due to several stimuli such as infections and chemicals can be replaced by the new liver tissue in just a few days. ${ }^{25}$ The present study is intended to investigate the toxicity of $C$. filiformis extract to the liver function, including in the metabolism as the main role of this organ. In addition, the reversibility of this toxic effect is also studied through the determination of liver enzymes activity.

\section{MATERIALS AND METHODS}

\section{Drugs and chemicals}

Ethanol and n-hexane were purchased from Bratachem (Brataco PT, Indonesia). Propofol (Fresofol') was the product of Fresenius Kabi (Indonesia). The assay kit of alanine transaminase (ALT) and alkaline phosphatase (ALP) was purchased from DiaSys Diagnostic Systems $\mathrm{GmbH}$ (Germany). All materials were used as received.

\section{Cassytha filiformis extract preparation}

The extract was produced from the whole part of Cassytha filiformis plant (family Lauraceae) collected from Padang City, West Sumatra, Indonesia. The exact species of the plant was confirmed in Herbarium of Andalas University (ANDA). The entire extraction process was conducted according to our previous work. ${ }^{12}$

\section{Determination of hepatotoxicity of Cassytha filiformis extract}

A number of 72 male mice weighing 25-30 g and aged 2-3 months old were acclimatized to normal laboratory condition for one week before any experimental procedure. The mice were provided drinking water and standard chow ad libitum. A half of the animals were used for the determination of sleep time, while another half were used to evaluate serum alanine transaminase (ALT) activity. The animals received daily oral administration of $C$. filiformis extract (CFE) at the doses of 2.5; 5; and $10 \mathrm{mg} / \mathrm{kg}$ with a control group receiving distilled water. All formulas were added with surfactant to produce a homogenous suspension. The animals were also grouped based on the duration of administration: 1 , 3 and 7 days.

The evaluation of sleeping time behavior consisted of sleep onset time (SOT) and duration of sleep (DOS). Propofol $140 \mathrm{mg} / \mathrm{kg}$ was administered through intraperitoneal injection $2 \mathrm{~h}$ after the last administration of the extract to induce sleep. The SOT and DOS were recorded by using the loss and recovery of righting reflex. ${ }^{26}$ Meanwhile, ALT activity was determined using UV-Visible spectrophotometry (Shimadzu-1700, Japan).

\section{Evaluation of reversibility of liver toxicity}

Another 36 male mice were divided into 3 groups and treated with CFE at the doses of 5,10 and $20 \mathrm{mg} / \mathrm{kg}$ orally. The extract was discontinued after 7 days administration. The activities of alanine transferase (ALT) and alanine phosphatase (ALP) were determined on day 0, 1, 3 and 7 after the discontinuation of CFE administration. The liver weight ratio was also measured. All protocols for the animals have been approved by the Ethics Committee of Faculty of Medicine, Andalas University No. 083/KEP/FK/2016.

\section{Statistical analysis}

The data were presented as mean \pm SEM. A two-way analysis of variance (ANOVA) was used for multiple comparisons of toxicity parameters. Any significant variation within groups was further analyzed by Duncan's multiple range test. The reversibility of parameters after discontinuation of extract administration was analyzed with Pearson's correlation. $P$ values of $<0.05$ were considered to be statistically significant for all analyses.

\section{RESULTS}

\section{Effect of Cassytha filiformis extract to sleep onset time (SOT)}

Both doses and duration of $C$. filiformis extract (CFE) administration influenced the sleep onset time (SOT) significantly $(p<0.05)$. All doses of the extract caused a significant delay in the SOT as compared with control. However, there was no significant variation of SOT among the extract doses. In contrast, the duration of treatment caused a significant variation in the SOT, in which the longer the duration of treatment, the shorter the SOT. The shortest onset was demonstrated by the highest dose of extract $(10 \mathrm{mg} / \mathrm{kg}$ ) and the longest duration of treatment (7 days). This indicates a strong effect of the extract treatment to the function of the liver in the metabolism of propofol. The SOT of the mice after the administration of the extract is presented in Table 1.

\section{Effect of Cassytha filiformis extract to the duration of sleep (DOS)}

The doses and duration of $C$. filiformis extract (CFE) treatment also influenced the duration of sleep (DOS) significantly $(p<0.05)$. Extract in the doses of 5 and $10 \mathrm{mg} / \mathrm{kg}$ caused a significant increase in the DOS as compared with control. Higher doses were likely to prolong the DOS. Meanwhile, the duration of treatment caused a significant variation in the DOS. Seven days of treatment caused the longest DOS and was significantly different as compared with 1 and 3 days of treatment. The longest DOS was demonstrated by the highest dose of extract, $10 \mathrm{mg} / \mathrm{kg}$. The DOS of the mice after the administration of the extract is presented in Table 2. The effect of CFE to the sleep time (both SOT and DOS) is shown in Figure 5.

\section{Effect of Cassytha filiformis extract to the activity of alanine transferase (ALT)}

The administration of extract caused a significant difference to the activity of ALT $(p<0.05)$. Higher doses increased the average activity of ALT, indicating that the extract induced a liver injury. Meanwhile, the duration of treatment did not cause a significant variation to the average

Table 1: The influence of Cassytha filiformis extract to sleep onset time.

\begin{tabular}{ccccc}
\hline \multirow{2}{*}{$\begin{array}{c}\text { Doses } \\
(\mathrm{mg} / \mathrm{kg})\end{array}$} & \multicolumn{3}{c}{ Sleep onset time (second) } & \\
\cline { 2 - 4 } & 1 day & 3 days & 7 days & Average \\
\hline Control & $279 \pm 35.01$ & $260 \pm 9.07$ & $255 \pm 33.93$ & $264.8 \pm 14.77^{\mathrm{a}}$ \\
Extract 2.5 & $376 \pm 39.75$ & $325 \pm 11.83$ & $278 \pm 17.70$ & $326.8 \pm 19.19^{\mathrm{b}}$ \\
Extract 5 & $387 \pm 42.21$ & $367 \pm 20.95$ & $193 \pm 24.47$ & $316.8 \pm 34.38^{\mathrm{b}}$ \\
Extract 10 & $424 \pm 33.22$ & $303 \pm 7.57$ & $216 \pm 22.21$ & $314.7 \pm 32.32^{\mathrm{b}}$ \\
Average & $366.8 \pm 30.92^{\mathrm{p}}$ & $314.0 \pm 22.49^{\mathrm{q}}$ & $236.1 \pm 19.00^{\mathrm{r}}$ & \\
\hline
\end{tabular}

Data are expressed as mean \pm SEM. Average data with different superscript are significantly different $(P<0.05)$. 
Table 2: The influence of Cassytha filiformis extract to the duration of sleep.

\begin{tabular}{ccccc}
\hline \multirow{2}{*}{$\begin{array}{c}\text { Doses } \\
(\mathrm{mg} / \mathrm{kg})\end{array}$} & \multicolumn{3}{c}{ Duration of sleep (second) } & \\
\cline { 2 - 4 } & 1 day & 3 days & 7 days & Average \\
\hline Control & $1877 \pm 218.41$ & $1738 \pm 134.87$ & $1933 \pm 295.32$ & $1849 \pm 116.62^{\mathrm{a}}$ \\
Extract 2.5 & $1879 \pm 232.89$ & $2409 \pm 338.00$ & $1619 \pm 142.18$ & $1969 \pm 170.97^{\mathrm{a}}$ \\
Extract 5 & $1584 \pm 188.48$ & $2443 \pm 144.36$ & $4804 \pm 363.78$ & $2944 \pm 497.44^{\mathrm{b}}$ \\
Extract 10 & $1737 \pm 82.56$ & $3198 \pm 66.06$ & $4084 \pm 144.46$ & $3006 \pm 345.97^{\mathrm{b}}$ \\
Average & $1769 \pm 180.59^{\mathrm{p}}$ & $2447 \pm 170.83^{\mathrm{q}}$ & $3110 \pm 236.44^{\mathrm{r}}$ & \\
\hline
\end{tabular}

Data are expressed as mean \pm SEM. Average data with different superscript are significantly different $(P<0.05)$.

Table 3: The influence of Cassytha filiformis extract to ALT activities.

\begin{tabular}{ccccc}
\hline \multirow{2}{*}{$\begin{array}{c}\text { Doses } \\
(\mathrm{mg} / \mathrm{kg})\end{array}$} & \multicolumn{3}{c}{ ALT Activity (IU/L) } & \\
\cline { 2 - 4 } & 1 day & 3 days & 7 days & Average \\
\hline Control & $53.92 \pm 7.606$ & $51.06 \pm 8.672$ & $48.23 \pm 2.344$ & $51.06 \pm 3.496^{\mathrm{a}}$ \\
Extract 2.5 & $60.14 \pm 9.269$ & $57.35 \pm 7.982$ & $53.73 \pm 5.502$ & $57.07 \pm 3.982^{\mathrm{a}}$ \\
Extract 5 & $51.61 \pm 7.996$ & $62.39 \pm 3.626$ & $64.26 \pm 4.160$ & $59.42 \pm 3.428^{\mathrm{ab}}$ \\
Extract 10 & $54.99 \pm 3.485$ & $70.29 \pm 10.644$ & $84.20 \pm 5.461$ & $69.83 \pm 5.543^{\mathrm{b}}$ \\
Average & $55.17 \pm 1.801^{\mathrm{p}}$ & $60.27 \pm 4.062^{\mathrm{p}}$ & $62.60 \pm 7.933^{\mathrm{p}}$ & \\
\hline
\end{tabular}

Data are expressed as mean \pm SEM. Average data with different superscript are significantly different $(P<0.05)$.

Table 4: Reversibility of liver function after the termination of Cassytha filiformis extract treatment.

\begin{tabular}{cccccc}
\cline { 1 - 3 } \cline { 4 - 5 } \cline { 4 - 5 } & & \multicolumn{3}{c}{ Correlation score } \\
\cline { 4 - 6 } Day after extract & $\mathrm{r}$ & $0.518^{* *}$ & $-0.530^{* *}$ & $-0.333^{*}$ \\
discontinued & $\mathrm{p}$ & 0.001 & 0.001 & 0.047 \\
& $\mathrm{n}$ & 36 & 36 & 36 \\
\hline
\end{tabular}

Analyzed with Pearson Product-Moment Correlation $(\mathrm{r}=$ Pearson correlation coefficient; $\mathrm{p}=$ significance level; $\mathrm{n}=$ number of data). ${ }^{* *}$ Correlation is significant at the 0.01 level, ${ }^{*}$ correlation is significant at the 0.05 level.

ALT ( $p>0.05)$, but the extract caused an increase for a longer duration treatment, especially in the doses of 5 and $10 \mathrm{mg} / \mathrm{kg}$. The ALT activity of the mice after the administration of CFE is shown in Table 3.

\section{Liver weight ratio after the termination of Cassytha filiformis extract administration}

The liver weight ratio of the mice was significantly correlated with the day after discontinuation of extract administration $(P<0.05)$ and significantly affected by the dose of the extract. The liver weight ratio of the mice increased with time according to dose (Figure 1). The correlation coefficient of liver weight ratio with time is 0.518 and the scatter plot of the correlation is shown in Figure 5A.

\section{Activities of alanine transferase (ALT) and alkaline phosphatase (ALP) after the termination of Cassytha filiformis extract administration}

The ALT activity was significantly correlated with time after discontinuation of extract $(p<0.05)$. The animal ALT levels decreased over time and

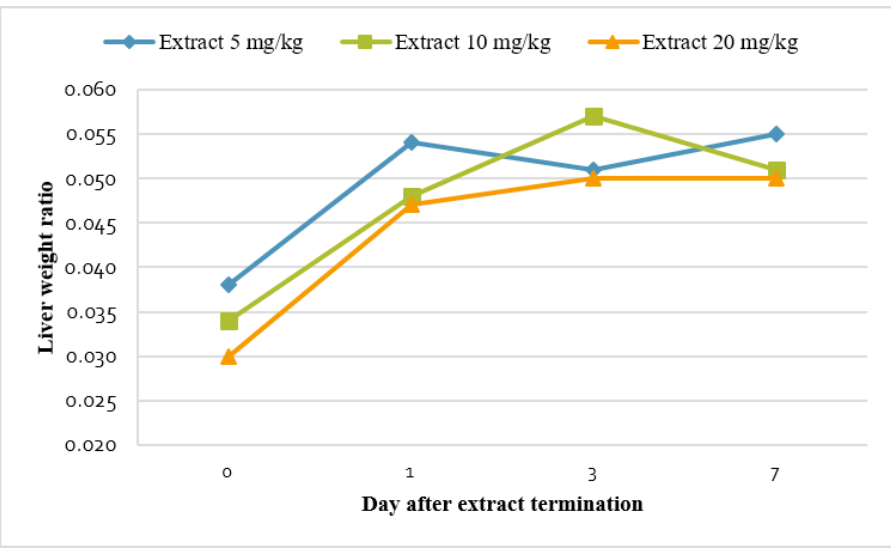

Figure 1: Liver weight ratio after the termination of Cassytha filiformis extract treatment.

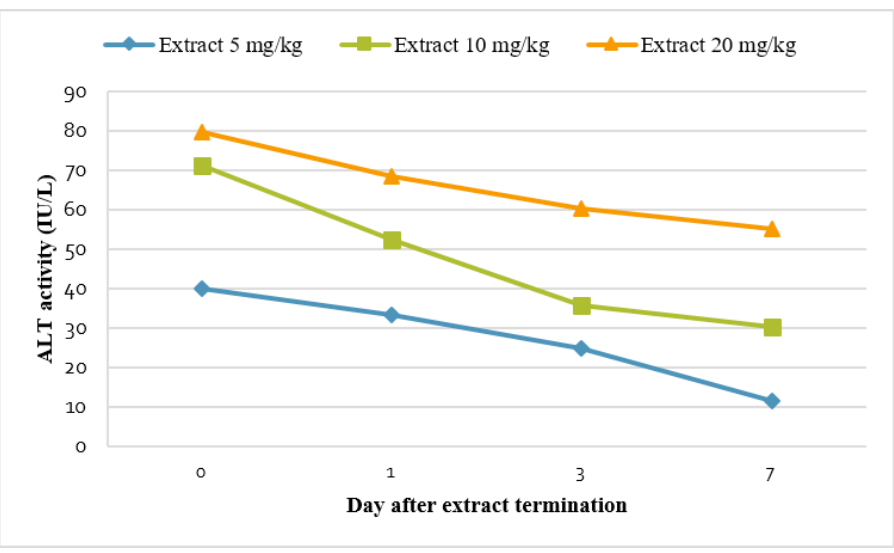

Figure 2: Activity of alanine transferase (ALT) after the termination of Cassytha filiformis extract treatment.

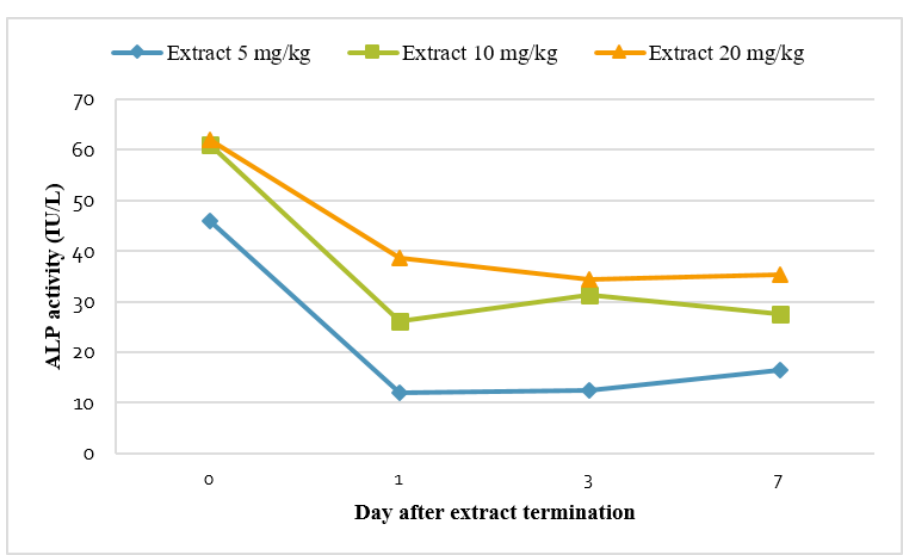

Figure 3: Activity of alkaline phosphatase (ALP) after the termination of Cassytha filiformis extract treatment.

proportional to the dose. The ALT of the animals treated with lower dose decreased faster compared to those treated with higher dose. Similarly, the animal ALP activity after discontinuation of CFE administration was significantly affected by dose and time $(p<0.05)$. The ALP activity also decreased after administration of the extract was discontinued and was accordingly to the dose. The decrease of ALT and ALP activities after 


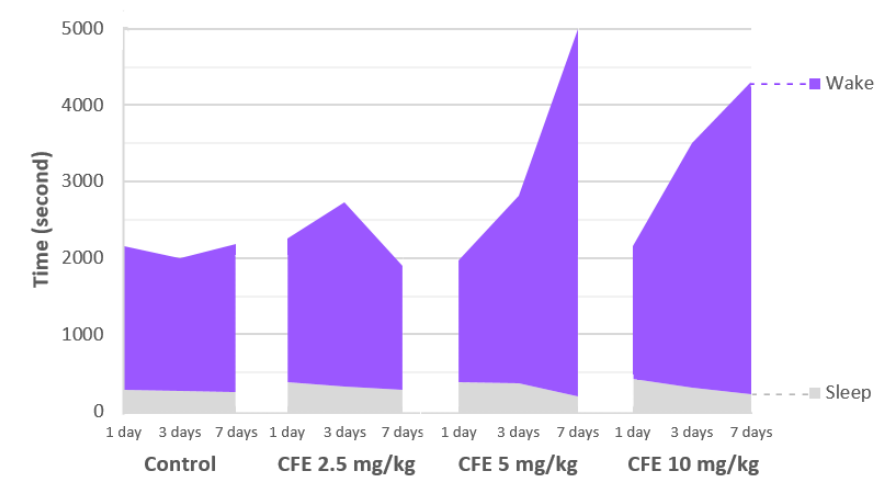

Figure 4: Effect of Cassytha filiformis extract on propofol-induced sleep time in mice.
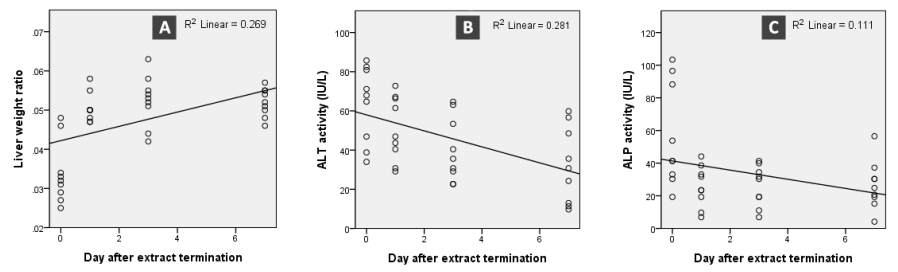

Figure 5: Scatter plots showing the reversibility of liver function after the termination of Cassytha filiformis extract treatment: $A$ ) liver weight ratio, $R^{2}=$ $0.269 ; B$ ) alanine transferase (ALT) activity, $R^{2}=0.281$; and C) alkaline phosphatase (ALP) activity $\mathrm{R}^{2}=0.111$

discontinuation of the extract are demonstrated in Figure 2 and 3. The correlation coefficient of ALT and ALP with time are -0.530 and -0.333 , respectively (Table 4). The scatter plots of the correlation is shown in Figure 5B and 5C.

\section{DISCUSSION}

The new concept in herbal medicine suggests that natural products may come as a good solution along with current best medical practices. One very important aspect to take into account is to promote high-quality studies to pursue "evidence-based herbal medicine", including the evaluation of its safety. ${ }^{1}$ Consequently, the very potential of Cassytha filiformis should be explored for its safety data, mainly for major organs. The possible toxicity of this plant to the liver, one of the most common organs that may be damaged from the use of herbal remedies, needs to be examined. In addition, the reversibility of its toxic effect is also an important attribute since the liver is a metabolizing organ with an amazing regenerative capacity. ${ }^{24}$ This information will guide those interested in preparing a product using this plant, especially for dose arrangement in order to guarantee its safe use.

In this study, we investigated the toxic effect of seven days use of C. filiformis extract to the liver function of mice using enzyme activity and sleep time in propofol-induced sedation as indicators. The reversibility of the toxic effect was furtherly studied through the trend of liver weight ratio and enzymes activity changes in seven days after the extract treatment was terminated. We found that the extract exhibited hepatotoxicity indicated by a significant decrease in liver function. However, this toxic effect was reversible, in which the indicators of liver function were approaching the normal rate after the discontinuation of extract treatment.

Propofol is a popular sedative agent well known for its rapid onset of action, short half-life and favorable recovery profile for anesthesia.
The metabolism of propofol is mainly in the liver, bio transformed via a cytochrome P-450 dependent pathway or undergoes quick direct glucuronidation. ${ }^{27}$ The damaged liver may cause a disturbance in the metabolism of propofol, resulting in the altered pharmacokinetic profile of the drug, predominantly the onset time and the duration of action. Therefore, the sleep onset time (SOT) and duration of sleep (DOS) due to the administration of propofol are valuable parameters to assess the function of the liver. In addition, the sleeping behavior is closely related to the function of the liver. Some human studies have confirmed that liver injury, such as cirrhosis, can cause major changes in sleep pattern. The degree and quality of sleep are also reported to correlate to the liver function..$^{28-29}$

The hepatotoxicity of $C$. filiformis extract in the present study was confirmed by a significant delay in the onset of action of propofol, indicated by earlier sleep of the mice (Table 1). Altered liver function due to the extract is also indicated by the prolongation of propofol effect. The data demonstrate a significant increase of sleep time in mice treated with higher dose or longer duration of extract administration (Table 2). Propofol is basically a short-acting anesthesia. The short duration of effect of propofol is reported due to its rapid clearance combined with its slow diffusion to central compartment. This drug is metabolized in the liver to less active metabolites that can be eliminated through renal excretion. ${ }^{30-31}$ In the present study, the extract is likely to cause a decrease on the biotransformation of propofol to its less active metabolites, resulting in prolonged duration of sedation effect. Figure 4 demonstrates the sleep and wake time of the mice treated with multiple doses and different duration of extract treatment.

Liver cell damage begins with an exposure of liver cell membranes to toxic substances resulting in an increase in cell membrane permeability. This condition will lead to a decrease in its ability to prevent passive diffusion of ions from entering the cell. The extracellular calcium ion enters the cell and accumulates in the mitochondria causing swelling that triggers mitochondrial damage. The accumulation of calcium ions in the mitochondria disrupts the metabolism of oxidative phosphorylation, decreases oxidative phosphorylation and ATP, as well as disturbs the ionic balance. These will result in a decrease of cell $\mathrm{pH}$ that will affect and damage the lysosome membrane, resulting in the breakdown of lysosomes and the release of enzymes into the cytoplasm. ${ }^{32}$

On the other hand, a decrease in ATP production will also decrease $\mathrm{Na}^{+} \mathrm{K}^{+} \mathrm{ATPase}$ function. This situation will lead to an accumulation of intracellular $\mathrm{Na}+$ and increases the cellular osmotic pressure. The water directly passes passively from outside of the cell into the cell following the concentration gradient and causes continuous cell swelling resulting in cell lysis. As the result, cell wall will rupture and intracellular enzymes will be released into the bloodstream. An increase of these enzymes, e.g. alanine transferase (ALT), is a good marker of liver cells damage. ${ }^{33}$

In this study, the activity of ALT and ALP enzymes increased after the administration of $C$. filiformis extract, despite their levels were ranged within normal values. This indicates that the extract is slightly toxic to the liver. Toxic effect of this extract is also reported by Quetin et al. who describes that the alkaloid contents of this plant exhibit cytotoxic activity with a non-specific topoisomerase I and II inhibition mechanism. ${ }^{16-17}$ This non-selective inhibition may also affect the normal liver cells and cause cell damage. ${ }^{34}$

Fortunately, the toxic effect on the liver function is reversible, indicated by the decrease of mice ALT and ALP on day 3 to 7 after the extract was discontinued, depending on dose. The lower the dose, the faster the recovery. The liver weight ratio also indicates the recovery of the organ significantly, along with the decrease of enzyme activity (Table 4). The correlation of the dose and the recovery of the organ is shown in Figure 5. 
The process of cell regeneration takes different time in different organisms. This cell regeneration depends on the cell proliferation process. For mice, the peak proliferation of its cells takes about $24 \mathrm{~h}$, with the peak of 36-42 h. ${ }^{35}$ Liver cell injury found in this study is indicated by a decrease in the liver weight ratio especially in mice treated with high dose but then increased by time. Weight loss of the liver may result from the lysis of hepatocytes. Thus, the toxic effect of the extract on the liver decreases its size but then returns to normal due to the liver cell regeneration.

\section{CONCLUSION}

In conclusion, these results suggest that the defatted extract of Cassytha filiformis is toxic to the liver, but the toxicity is reversible depending on the dose. More toxicity studies of this plant to other organ systems are required to support its safe use beyond its potential efficacy.

\section{ACKNOWLEDGEMENT}

The authors acknowledge Andalas University, Indonesia for financial support of the study under the scheme of "Riset Guru Besar" 2017 (Contract Number 13/UN.16.17/PP.HGB/LPPM/2017).

\section{CONFLICT OF INTEREST}

The authors declared no conflict of interest.

\section{ABBREVIATIONS}

ALP: Alkaline phosphatase; ALT: Alanine transaminase; ANOVA: Analysis of variance; ATP: Adenosine triphosphate; CFE: Cassytha filiformis extract; DOS: Duration of sleep; SOT: Sleep onset time; WHO: World Health Organization.

\section{REFERENCES}

1. Carmona F, Pereira AMS. Herbal medicines: Old and new concepts, truths and misunderstandings. Brazilian J Pharmacogn. 2013;23(2):379-85. doi:10.1590/ S0102-695X2013005000018.

2. Navarro VJ, Seeff LB. Liver injury induced by herbal complementary and alternative medicine. Clin Liver Dis. 2013;17(4):715-35. doi:10.1016/j.cld.2013.07.006

3. Kamsu-Foguem B, Foguem C. Adverse drug reactions in some African herbal medicine: literature review and stakeholders' interview. Integr Med Res. 2014;3(3):126-32. doi:10.1016/j.imr.2014.05.001.

4. Kalaiselvan V, Saurabh A, Kumar R, Singh GN. Adverse reactions to herbal products: An analysis of spontaneous reports in the database of the Pharmacovigilance Programme of India. J Herb Med. 2015;5(1):48-54. doi:10.1016/J. HERMED.2015.01.006.

5. Kim M, Han C ho. Adverse drug reactions in Korean herbal medicine: A prospective cohort study. Eur J Integr Med. 2017;9:103-9. doi:10.1016/j.eujim.2016.11.016.

6. Ernst E. Harmless herbs? A review of the recent literature. Am J Med. 1998;104(2):170-8. doi:10.1016/S0002-9343(97)00397-5.

7. Elvin-Lewis M. Should we be concerned about herbal remedies. J Ethnopharmacol. 2001;75(2-3):141-64. doi:10.1016/S0378-8741(00)00394-9

8. Hussin AH. Adverse Effects Of Herbs And Drug-Herbal Interactions. Malaysian J Pharm. 2001;1(2):39-44.

9. WHO. WHOTraditional Medicine Strategy 2014-2023. World Health Organization (WHO). 2013.

10. WuY, Chang F, Chao Y, Teng C. Antiplatelet and vasorelaxing actions of aporphinoids from Cassytha filiformis. Phyther Res. 1998;12(S1):S39-41.

11. Armenia A, Yuliandra Y, Sattar MZA. Comparative effectiveness of defatted hypotensive crude extract, ethyl acetate and butanolic fractions of Cassytha filiformis L. on different models of hypertensive rats. World J Pharm Pharm Sci. 2014;3(12):200-8.

12. Yuliandra $Y$, Armenia A, Arifin $H$. Antihypertensive and antioxidant activity of Cassytha filiformis L.: A correlative study. Asian Pac J Trop Biomed. 2017;7(7):614-8. doi:10.1016/j.apjtb.2017.06.007.
13. Sharma S, Hullatti K, Prasanna S, Kuppast I, Sharma P. Comparative Study of Cuscuta reflexa and Cassytha filiformis for Diuretic Activity. Pharmacognosy Res. 2009;1 (5):327-30.

14. Armenia N, Alen Y, Ismed F, Yuliandra Y, Ananda R, Fitria F. Blood sugar lowering effectiveness of Cassytha filiformis fractions on diabetic mice. Res J Pharm Biol Chem Sci. 2016;7(6):1142-7.

15. Aguwa CN. Uterotonic activity of Cassytha filiformis. Fitoterapia. 1987;58(5):291-4.

16. Stévigny C, Block S, De Pauw-Gillet MC, De Hoffmann E, Llabrès G, Adjakidjé V, et al. Cytotoxic aporphine alkaloids from Cassytha filiformis. Planta Med. 2002;68(11):1042-4. doi:10.1055/s-2002-35651.

17. Hoet S, Stévigny C, Block SS, Opperdoes FF, Colson P, Baldeyrou B, et al. Alkaloids from Cassytha filiformis and related aporphines: Antitrypanosomal activity, cytotoxicity and interaction with DNA and topoisomerases. Planta Med. 2004;70(5):407-13. doi:10.1055/s-2004-818967.

18. Soidrou SH, Bousta D, Lachkar M, Hassane SOS, Youbi-Hamsas A El, Mansouri L El, et al. Immunomodulatory Activity of Phenolic Fraction from Piper Borbonense and Cassytha Filiformis Growing in Comoros Islands. In: Chemistry: The Key to our Sustainable Future. Dordrecht: Springer Netherlands. 2014. doi:10.1007/978-94-007-7389-9_7.

19. Khan M. Antibacterial Activity of Some Tanzanian Medicinal Plants. Pharm Biol. 2001;39(3):206-12. doi:10.1076/phbi.39.3.206.5927.

20. Jadhav N, Kulkarni S, Mane A, Kulkarni R, Palshetker A, Singh K, et al. Antimicrobial activity of plant extracts against sexually transmitted pathogens. Nat Prod Res. 2015;29(16):1562-6. doi:10.1080/14786419.2014.983919.

21. Babayi HM, Udeme JJI, Abalaka JA, Okogun JI, Salawu OA, Akumka DD, et al. Effect of oral administration of aqueous whole extract of Cassytha filiformis on haematograms and plasma biochemical parameters in rats. J Med Toxicol. 2007;3(4):146-51. doi:10.1007/BF03160930.

22. Yuliandra Y, Armenia N, Salasa AN, Ismed F. Subchronic toxicity of ethanolic extract of Cassytha filiformis L. on the renal function of rat. J Sains Farm Klin. 2015;2(1):54-9. doi: 10.29208/jsfk.2015.2.1.47.

23. Armenia N, Gustinanda D, Salasa AN, Yuliandra Y. Acute and delayed toxicity study of Cassytha filiformis defatted ethanolic extract. World J Pharm Pharm Sci. 2015;4(10):155-62.

24. Fausto N. Liver regeneration and repair: Hepatocytes, progenitor cells and stem cells. Hepatology. 2004;39(6):1477-87. doi:10.1002/hep.20214.

25. Michalopoulos GK. Advances in liver regeneration. Expert Rev Gastroenterol Hepatol. 2014;8(8):897-907. doi:10.1586/17474124.2014.934358.

26. Hock FJ. Drug discovery and evaluation: Pharmacological assays. 4th ed. Drug Discovery and Evaluation: Pharmacological Assay, Fourth Edition. Springer International Publishing; 2015.

27. Aronson JK. Meyler's Side Effects of Drugs Used in Anesthesia. Elsevier BV. 2008.

28. Mabrouk AA, Nooh MA, Azab NY, Elmahallawy II, Elshenawy RHM. Sleep pattern changes in patients with liver cirrhosis. Egypt $J$ Chest Dis Tuberc. 2012;61(4):447-51. doi:10.1016/j.ejcdt.2012.09.012.

29. Samanta J, Dhiman RK, Khatri A, Thumburu KK, Grover S, Duseja A, et al. Correlation between degree and quality of sleep disturbance and the level of neuropsychiatric impairment in patients with liver cirrhosis. Metab Brain Dis. 2013;28(2):249-59. doi:10.1007/s11011-013-9393-3.

30. Simons PJ, Cockshott ID, Douglas EJ, Gordon EA, Hopkins K, Rowland M Disposition in male volunteers of a subanaesthetic intravenous dose of an oil in water emulsion of 14 C-propofol. Xenobiotica. 1988;18(4):429-40. doi:10.3109/00498258809041679.

31. Veroli P, O'kelly B, Bertrand F, Trouvin JH, Farinotti R, Ecoffey C. Extrahepatic metabolism of propofol in man during the anhepatic phase of orthotopic liver transplantation. Br J Anaesth. 1992;68(2):183-6. doi:10.1093/bja/68.2.183.

32. Singh K, Ahluwalia P. Studies on the effect of monosodium glutamate (MSG) administration on the activity of xanthine oxidase, superoxide dismutase and catalase in hepatic tissue of adult male mice. Indian $\mathrm{J}$ Clin Biochem. 2002;17(1):29-33. doi:10.1007/BF02867938.

33. Zechini B, Pasquazzi $C$, Aceti $A$. Correlation of serum aminotransferases with HCV RNA levels and histological findings in patients with chronic hepatitis C: the role of serum aspartate transaminase in the evaluation of disease progression. Eur J Gastroenterol Hepatol. 2004;16(9):891-6. doi:10.1097/00042737200409000-00013.

34. Pommier Y, Yu Q, Kohn KW. Novel Targets In The Cell Cycle And Cell Cycle Checkpoints. In: Baguley BC, Kerr DJ, editors. Anticancer drug development. Academic Press. 2002.

35. Kang LI, Mars WM, Michalopoulos GK. Signals and cells involved in regulating liver regeneration. Cells. 2012;1(4):1261-92. doi:10.3390/cells1041261.

Cite this article: Yuliandra Y, Armenia A, Arief R, Jannah MH, Arifin $\mathrm{H}$. Reversible Hepatotoxicity of Cassytha filiformis Extract: Experimental Study on Liver Function and Propofol-Induced Sleep in Mice. Pharmacog J. 2019;11(1):69-74. 
GRAPHICAL ABSTRACT

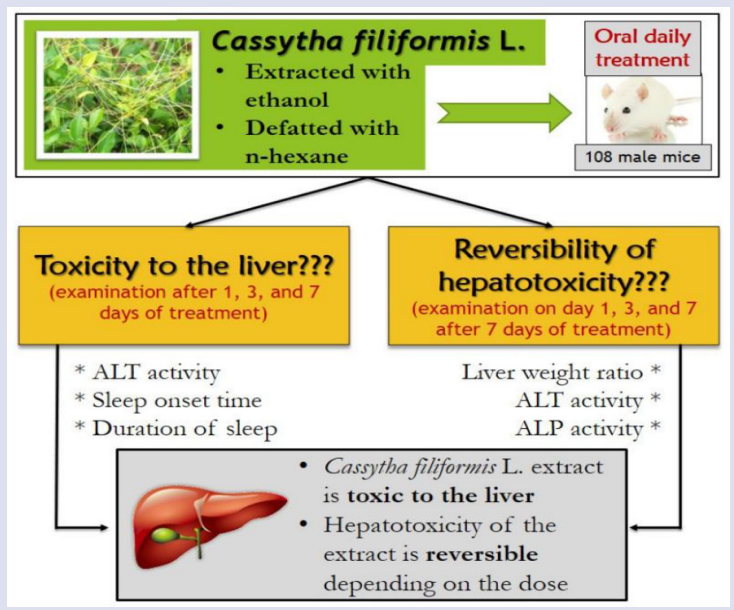

\section{SUMMARY}

- Cassytha filiformis was extracted by using ethanol and then further defatted with $n$-hexane. The extract was administered orally to the mice to investigate the hepatotoxicity of the extract and its reversibility.

- The extract caused hepatotoxicity, indicated by increased activity of alanine transferase (ALT) and alteration on the metabolism of propofol that was induced to the mice.

- Altered metabolism of propofol was marked by the delay on the sleep onset time (SOT) and prolongation on the duration of sleep (DOS) in propofol-induced sleep in mice.

- The hepatotoxicity of the extract was reversible, indicated by improved liver weight ratio and decreased activity of alanine transferase (ALT) and alkaline phosphatase (ALP) after the termination of the extract.

- The reversibility of hepatotoxicity of Cassytha filiformis was depending on the dose, in which the lower dose and shorter duration of administration showed better recovery for the liver.

\section{ABOUT AUTHORS}

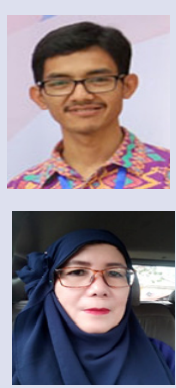

Yori Yuliandra, is a Postgraduate from Andalas University, Indonesia and presently working as a lecturer and researcher in the Faculty of Pharmacy, Andalas University. His research interest includes Pharmacology, Toxicology and Clinical Pharmacy. He has been very active in scholarly publications as the editor, peer reviewer, and the author as well. He is also an awardee of Australian Awards Scholarships 2019 intake.

Prof. Armenia, is a Professor of Pharmacology at the Faculty of Pharmacy, Andalas University, Indonesia. She has been researching the Pharmacological activity of some Indonesian medicinal plants mostly within cardiovascular system and diabetes, including their toxicological profile.

Prof. Helmi Arifin, is a Professor of Pharmacology at the Faculty of Pharmacy, Andalas University, Indonesia. $\mathrm{He}$ is the former dean of the faculty of Pharmacy medicinal plants effect for disease complications. 